\title{
頚部神経根症に対する椎間孔拡大術
}

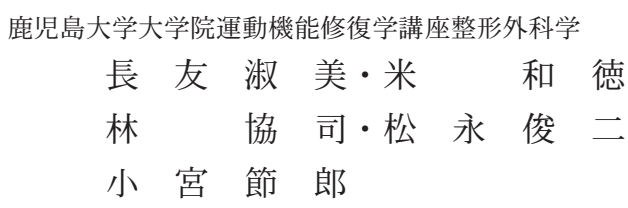

\section{Posterior Foraminotomy for Cervical Spondylotic Radiculopathy}

\author{
Yoshimi Nagatomo, Kazunori Yone, Kyoji Hayashi, \\ Shunji Matsunaga, and Setsuro Komiya \\ Department of Orthopaedic Surgery, \\ Kagoshima University, Kagoshima, Japan
}

\begin{abstract}
Anterior fusion is widely perfomed for cervical spondylotic radiculopathy, and good results are reported for posterior foraminotomy. We treated seven cases suffering from cervical spondylotic radiculopathy with this method from May 2000 to July 2003. They consisted of five men and two women with a mean age of 58 (44 to 48) years. The average period to the operation was 13 ( 3 to 48) months, and the follow-up period was 20 (3 to 41) months. Numbness decreased in five cases, pain decreased in four cases, and muscular power recovered in five cases. Though we were concerned about the developing instability of the cervical spine after foraminotomy because of partial facetectomy, but this did not occur. Posterior foraminotomy is a good operative method for cervical spondylotic radiculopathy.
\end{abstract}

Key words : cervical spondylotic radiculopathy（頸椎症性神経根症）, foraminotomy（椎間孔 拡大術), anterior fusion（前方固定）

\section{は じめ に}

今回我々は, 䅡部神経根症に対して後方進入椎間孔 拡大術を行い良好な結果を得たので若干の文献的考察 を加え報告する。

\section{対象と方法}

対象は平成 12 年 5 月から平成 15 年 7 月に手術施行 をした男性 5 例, 女性 2 例である. うち 2 例は, 頸椎 症性脊䯣症にて平成 6 年と平成 7 年に片開き式脊柱管 拡大術を施行した症例であった。手術時年齢は 44〜 68 歳, 平均 58 歳, 罹病期間は 3 ケ月 4 年, 平均 1 年 1 ケ月, 罹患椎間は, $\mathrm{C} 4 / 5$ が 2 例， C $4 / 5+\mathrm{C} 5 / 6$ が 4 例，C5/6+C6/7 が 1 例であった。手術は, 腹
臥位・頸椎中間位として行う. 棘突起上に小皮切を加 えてから棘突起にマーキングを行ってレベルを確認し た後, 傍脊柱筋を椎弓にそって骨膜下に剥離し, 椎間 関節を露出. 椎間関節内側縁を確認しこれを中心に約 $7 \mathrm{~mm}$ の開空を肉眼的に行う. 上下の椎弓根は部分的 に切除される. また椎体後縁の骨棘は切除しなかった. 術後経過観察期間は 3 ケ月 3 年 5 ケ月, 平均 1 年 8 ケ月であり, 検討項目として手術時間, 出血量, 症状 の改善, 手術椎間での椎間高・椎間角度の変化, すべ り・不安定性発生の有無について調べた.

$$
\text { 結果 }
$$

手術時間は 1 椎間あたり 38 分〜 1 時間 45 分，平均 58 分, また出血量は 1 椎間あたり少量 $357 \mathrm{~g}$, 平均 


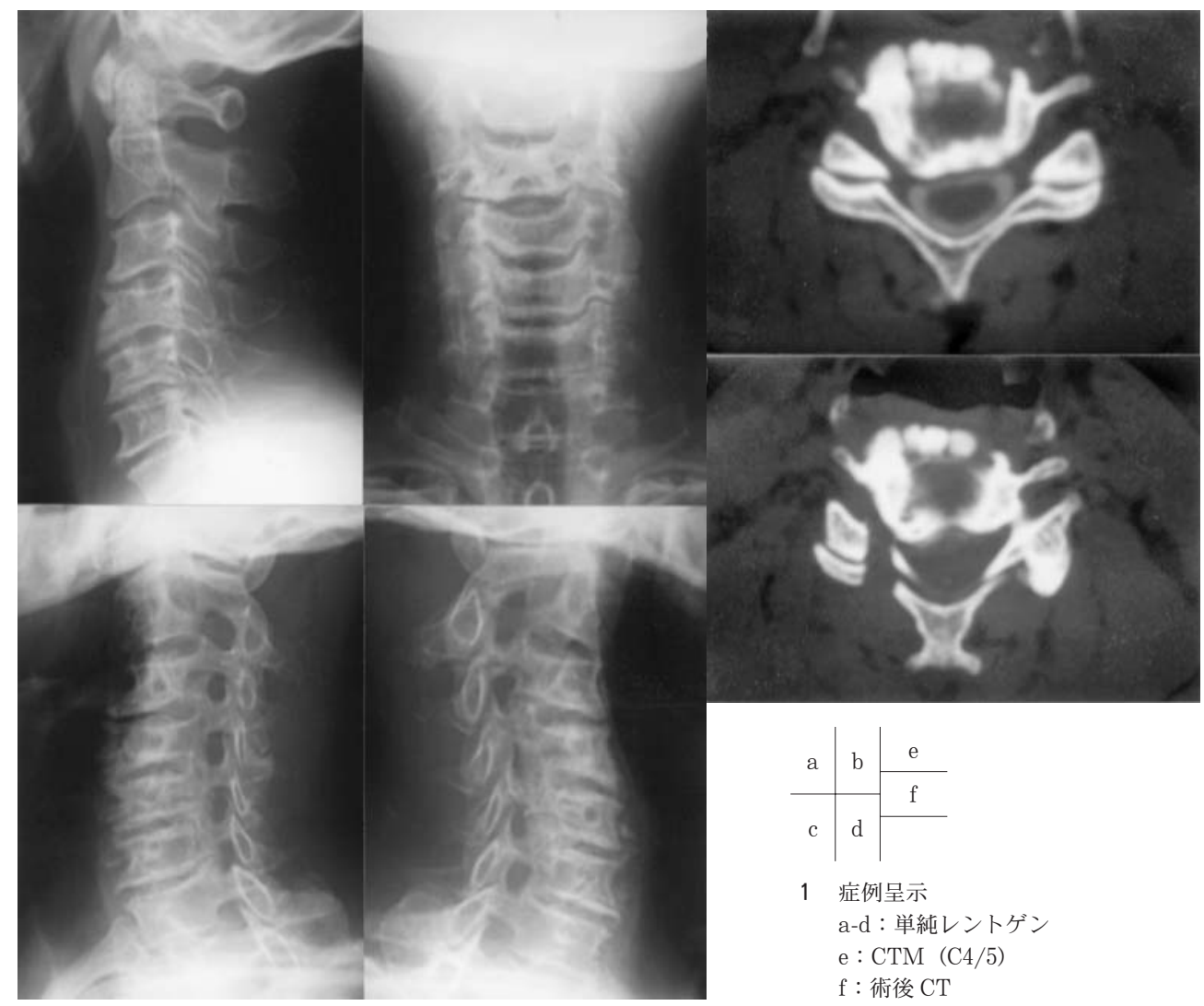

104g であった。手術時の合併症としては，1例で硬 脈外静脈叢から約 700cc の出血がみられたが, アビテ ンを使用することにより止血可能であった。 シビレは 7 例中 5 例に存在していたがそのうち 3 例で消失, 2 例で軽減していた。 疼痛は 7 例中 4 例に存在していた が， 2 例で消失， 2 例で軽減していた。筋力低下は 5 例に存在していたが, MMT で 2 段階改善したもの 1 例，1 段階改善したもの 4 例であった. 罹患椎間の椎 間高, 椎間角度は手術前後でまったく有意差はみられ なかつた。 また新たにすべりや不安定性を呈したもの はなかった．椎間関節を切除することで術後不安定性 を来すことが危惧されたが, 少ない症例数ではあるが 不安定性を呈したものは 1 例も認めなかつた.

\section{症 例 供 覧}

症例は 52 歳, 男性. 平成 14 年 6 月頃, ボディービ ルの訓練中右上肢の脱力に気づく．9月には右肩甲部
の筋萎縮を指摘された。平成 14 年 12 月, 近医受診し, 頸椎症性神経根症の診断にて平成 15 年 1 月, 当科紹 介受診となる. MMT は, 右肩外転・右肘屈曲ともに $\mathrm{G}$ ，右上腕二頭筋腱反射が低下していた。しびれ，痛 みはなく, 知覚も正常であった。右棘上筋, 棘下筋, 三角筋の筋萎縮を認めた．単純レントゲンでは，C4/ 5, C5/6，C6/7 で椎間高の減少，また骨棘による右 C4/5 椎間孔の著明な狭小化を認めた．MRI で脊髄圧 迫所見は認めなかったが, 右 $\mathrm{C} 4 / 5$ 椎間孔の狭小化を 認めた. CTM では，椎体後右縁の骨棘による右 $\mathrm{C} 4 / 5$ 椎間孔の狭小化を認めた。 以上の所見から C4/5 椎間 孔狭小化による C5 神経根障害と診断し, 後方進入椎 間孔拡大術を行った（図 1)。手術時間は 55 分，出血 量は少量であった。術後 2 日でカラー装着下に歩行開 始し, 術後 3 週間でカラーを除去した. 術後 6 ケ月現 在, 筋力は正常化している. 
考察

頸部神経根症は保存的療法によく反応すると言われ ている.しかしながら, 保存療法に抵抗する激しい痛 みを生じたり，筋力低下が進行して ADL 障害を来す 例が存在する.このような症例に対して前方除圧固定 術がよく行われてきた．前方除圧固定術は，ヘルニア や前方骨棘を直接除去することが出来，異常可動性の 是正が可能であるが，固定後の隣接椎間障害の問題が 残る. 最近では後方進入椎間孔拡大術の良好な成績が 報告されるようになってきた ${ }^{788}$. 椎間孔拡大術は, 前 方除圧固定術と比較して, 侵襲が小さく, 神経根が直 視可能で, 固定術が不要であり可動性を維持できるた め術後の隣接椎間障害の危惧がない，椎間関節内側を 切除するものの, 並川ら () の報告によると, 神経根の 確実な除圧に必要な切除量は約 $40 \%$ で術後不安定性 の心配はないと思われる. しかし硬膜外静脈叢からの 出血が問題としてあげられる. また, 頸椎後方手術に 伴う傍脊柱筋の侵襲による術後の項部愁訴を解決する ため, 八木ら ${ }^{99}$ は, 内視鏡を用いた後方進入椎間孔拡 大術を報告している.内視鏡であるので神経根, 静脈 叢が明るく拡大して見えるため安全な操作が行え, 出 血量も少ないようである. しかし狭い術野での操作で あること，また手術時間が長いことが問題としてあげ られている.

他の術式として，前方進入にて椎骨動脈を露出せず 椎間板外側を airtomeにて掘削することにより骨棘 やヘルニアを直接切除する前方椎間孔拡大術が報 告23) されている. 椎間板を部分的に切除するため椎 間不安定が危惧されたものの，むしろ椎間高は減少し 約 $1 / 3$ の症例で手術椎間の瘾合傾向がみられた ${ }^{2)}$ と述 べている.しかしながら椎骨動脈損傷の危険が伴うの で注意が必要であるし, 術野が狭く深く, 難度が高い ように思われる。

笹井 ${ }^{5 / 6)}$ は，臨床上神経根症を呈する症例と筋電 図上術後に神経根症の発生が予測される頝䯣症の症例 に対して en-bloc laminoplasty 併用顕微鏡下椎間孔 拡大術を行つている.これは圧迫が神経根に存在する か，根糸あるいは前角に存在するかを鑑別することが 不可能であるので椎弓形成術と椎間孔拡大術を併用す
ることによりすべての圧迫を除去できるので有用であ ると述べている.

臨床所見, 詳細な画像から明らかに神経根障害が病 因として考えられるなら椎間孔拡大術を, 脊髄前角細 胞が主に障害されているが索路症状を軽度来している ような頸椎症性脊䯣症の一病型が考えられるような場 合や多髄節にわたる症状がある症例に対しては $1 \sim 2$ 椎間なら前方除圧固定術を，より多椎間であれば春柱 管拡大術（場合により椎間孔拡大術を併用）を選択す べきであると思われる.

いずれにしても, 神経学的高位診断, 各種画像診断, 神経根ブロックなど注意深く行い，症例に応じ適切な 術式選択することが大切である。

結語

頸椎症性神経根症に対し, 後方進入椎間孔拡大術を 行い良好な結果を得た。

本術式は低侵襲で，早期の社会復帰が可能であり， 䫝部神経根症に対する外科的治療として有用な方法で ある.

\section{参 考 文 献}

1）早川 満ら：頸椎症性筋萎縮症に対する手術的治療. 日本脊椎脊髄病学会誌, 13(1)：105, 2002.

2) 河野 仁ら：頸椎神経根障害に対する前方椎間孔拡大 術の治療成績. 日本春椎脊䯣病学会誌, 14(1)：88, 2003

3) 森本哲也：頸椎椎間孔拡大術（神経根前方除圧）。春 椎脊髄, 15 (6)：569-574，2002.

4）並川 崇，乗上 啓，松田英樹：頸椎症性神経根症に 対する後方進入椎間拡大術の内側椎間関節切除量に関す る検討. 日本春椎春髄病学会誌, 12 (1)：270, 2001.

5）笹井邦彦ら：頸椎症性神経根症に対する椎弓形成術併 用顕微鏡視下椎間孔拡大術. 春椎 - 春髄神経手術手技, 4(1) : 76-79, 2002.

6) 笹井邦彦ら：頸椎神経根障害に対する椎弓形成術併用 顕微鏡視下椎間孔拡大術. 日本脊椎脊䯣病学会誌，12(1)： 269, 2001.

7）住田忠幸ら：頝部神経根症に対する顕微鏡下後方椎間 孔拡大術. 整・災外, $46: 489-495,2003$.

8) 田中靖久ら：Keegan 型, 麻痺の頝部神経根症に対す る椎間孔拡大術。日整会誌, 75(3)：S446, 2001.

9）八木省次ら：頸椎神経根症・脊髄症に対する内視鏡手 術. 日本脊椎春髄病学会誌, 14(1)：300, 2003.

10）山崎昭義ら：頝部神経根症に対する椎間孔拡大術. 日 本脊椎脊髄病学会誌, 14(1)：99, 2003. 